\title{
Food intakes, energy expenditures and faecal excretions of men on a polar expedition
}

\author{
By J. P. MASTERTON AND H. E. LEWIS* \\ British North Greenland Expedition, Division of Human Physiology, \\ Medical Research Council, Hampstead, London, N.W.3
}

AND ELSIE M. WIDDOWSON

Medical Research Council Department of Experimental Medicine, University of Cambridge

(Received I2 March 1957)

The British North Greenland Expedition (Lewis \& Masterton, 1955 $a, b$ ) provided an opportunity to study the food intake and energy expenditure of men in a cold environment. The expedition, consisting of twenty-five men, left London on 8 July I952 to spend 2 years in an unexplored area of mountains and glaciers situated some 800 miles from the North Pole. Their explorations included a geological and topographical survey involving considerable travelling, which was done by dog sledge.

For many years it has been reported by travellers to polar regions that husky dogs eat human faeces (Bertelsen, 1929; Rosendahl, 1954). This observation was confirmed by us and led to the present investigations. Sledging rations generally contain a high proportion of fat, which it was suggested might lead to an abnormally high excretion of fat in the faeces, which might be a physiological reason for the habits of the dogs.

The investigation now reported, carried out in association with the rest of the physiological work of the British North Greenland Expedition (Lewis \& Masterton, I $955 a, b)$, can be classified under five headings: (I) a record of the dietary intake of four men while sledging; (2) a record of these men's dietary intake on two occasions while living at the base hut; (3) an estimate of the energy expenditure of the four men while sledging and living at base; (4) an analysis of the nitrogen and fat in the faeces of two of the men while sledging; (5) an estimate of the calorie intake of the dogs, and the contribution of human faeces to it.

\section{EXPERIMENTAL}

The setting of the investigations. During the winter eighteen men lived at the Expedition base hut at Britannia Sø in north-east Greenland. The living quarters consisted of a common-room and cubicle dormitories, each occupied by four men. There was also a kitchen equipped with a slow-combustion stove. Leading from the living hut there was a laboratory hut.

The base hut was adequately heated, and during the winter $80 \%$ or more of the time was spent indoors. Conditions were crowded but reasonably comfortable, and the problem was that of living happily with one's fellows rather than that of struggling

* Previously Lecturer in Physiology, University College, London. 
against a very cold environment. The reverse was true whilst sledging. Fig. I shows the environmental conditions experienced by members of the Expedition.

The first dietary survey at the base was carried out after 17 months in Greenland. The men were at all times able to have as much food as they wanted. The quality was good, though fresh products and 'extras' were occasionally missed. The standard of cooking was satisfactory, the arrangement being that the men cooked in rotation, each
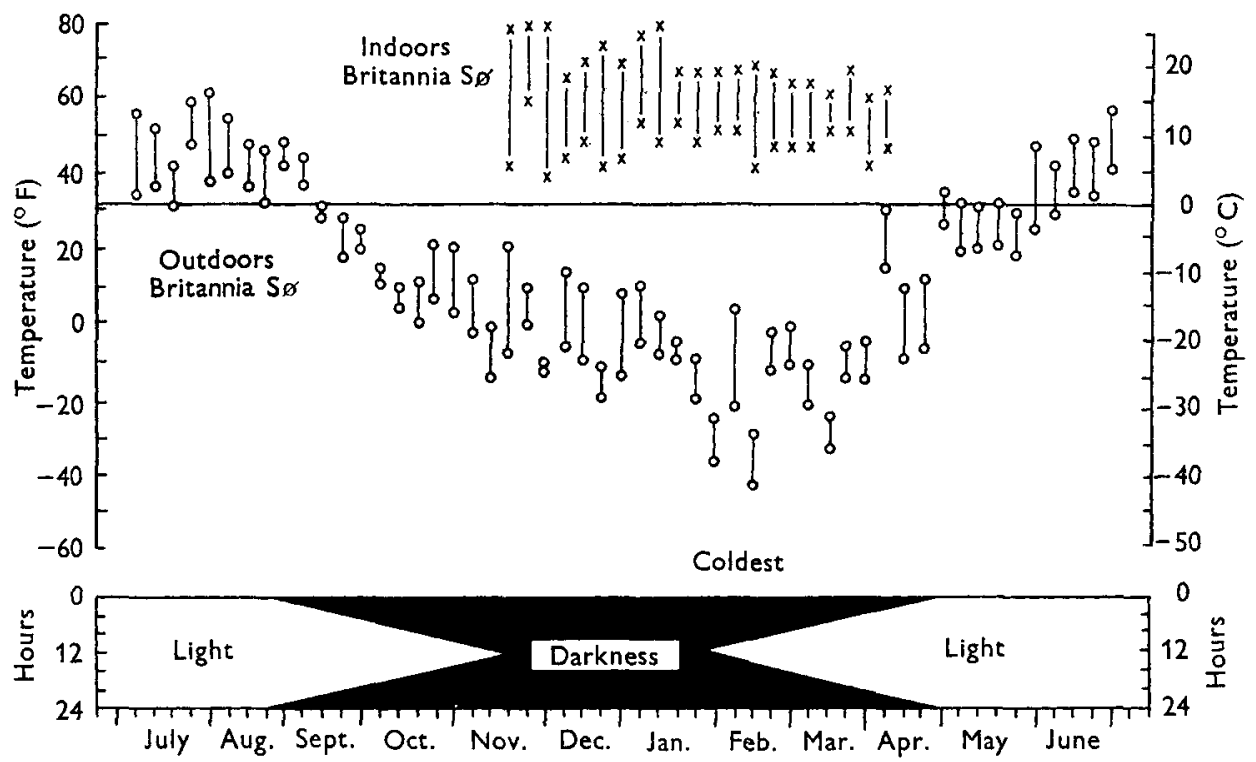

Fig. 1. Environmental conditions on the British North Greenland Expedition, at the base camp, Britannia Sø, 1952-3. The figures for 1954 were essentially similar. Latitude $77^{\circ} \mathrm{N}$. Maximum and minimum temperatures were recorded on the ist day of each week, indoors and outdoors, at the Main Laboratory, Britannia Lake. The bottom record of light and darkness shows that there is continuous sunlight from the last week in April till the end of August. There is no light from mid-November till the last week in January. The coldest time of the year is the middle of February.

for a week at a time. The range of cooked dishes was very wide, and included such things as rich birthday cakes, vol-au-vent and brandy snaps. A typical daily menu would consist of:

Breakfast: porridge or cornflakes, a cooked dish such as kippers or scrambled eggs (made with dried egg), bread, butter, jam, tea or coffee.

Mid-morning: tea or coffee, biscuits or bread.

Lunch: soup, usually Scotch broth, tomato or pea, boiled beef, potatoes and cabbage, stewed fruit with custard, coffee or tea, and bread.

Mid-afternoon: tea and biscuits with perhaps rich cake or some baked potato cakes.

Dinner (usually two, sometimes three courses, but always a sweet if lunch had included soup and vice versa): soup, bacon-and-egg pie, green peas, fried chipped potatoes, steamed pudding, coffee or tea, and bread.

Supper: Horlick's malted milk, coffee, cocoa, tea, or other beverage.

Eggs, kippers, or other snacks could be cooked by anyone who wished. On one occasion a very hungry man, for example, ate $16 \mathrm{oz}$. herring as a night-cap and another 
had about 9 oz. scrambled eggs before retiring to bed, but such appetites were exceptional. Other foods available were chocolate and boiled sweets. Alcohol was taken occasionally, but only once during the survey did it figure largely in the diet of two of the men. That was during a celebration of Burns Night. It was felt justifiable that this occasion should be included in the survey since parties were a regular feature of life at the base hut.

The sledging diet was rather different. In the early part of the Expedition a rigid régime was laid down. The only food taken was that in the sledging rations, and if a man was hungry after his day's ration had been eaten he had to remain so. By the time the dietary survey was carried out, 'extras' were often taken, and so, although the composition of the basic diet was constant, if a man was still hungry he could satisfy himself by eating extra chocolate, raisins, milk or biscuits. The standard daily ration in oz./man/day was: pemmican $5 \cdot 6$, butter $5 \cdot 6$, potato powder $1 \cdot 6$, cocoa $0 \cdot 4$, chocolate $2 \cdot 4$, sugar $3 \cdot 0$, oats $2 \cdot 3$, dried milk $\mathrm{I} \cdot 6$, biscuits (high-fat) $4 \cdot 3$. This ration provided $4 \mathrm{I} 64$ Cal. daily, made up from $99 \mathrm{~g}$ protein, $278 \mathrm{~g}$ fat and $3 \mathrm{IO} \mathrm{g}$ carbohydrate. As explained above, each man did not have exactly the same calorie intake every day, nor did he necessarily have the same as his fellow.

Work during the winter at the base involved cooking, fetching water, feeding dogs, repairing sledges and going for short sledge runs on the lake ice beside the hut The rest of the time was spent reading and doing laboratory work; the four subjects participated in all these activities. On a sledging expedition during the spring there was much greater activity, and life was much more regular. The men usually woke at about $8 \mathrm{a} . \mathrm{m}$. in their tent, in which the temperature was around $-15^{\circ}$. Breakfast and dressing followed and by 10 a.m. the tent was struck and loaded on to the sledge, and the dogs were harnessed. Then followed 6-8 h sledging or sledging combined with rock scrambling. There was usually one halt of ${ }_{5} \mathrm{~min}$ for lunch, which consisted of biscuits and chocolate. At about 5 p.m. a camp site was chosen on the glacier over which the party had been travelling, and it took an hour or more to pitch the tent, unload the sledge and feed the dogs. Once inside the tent the evening meal of pemmican was prepared, clothes were dried out, and by Io or I I p.m. the men were asleep. With minor variations, and lying up during blizzards, this was the constant daily routine.

Subjects of the investigation. Four men acted as subjects. They were engaged on topographical (R.B., J.M.) and geological (A.E., P.W.) surveys. Each man's food intake and his time spent at various occupations were measured for two periods: (I) at the base hut during the winter, and (2) on a sledging expedition. While the sledging dietary survey was in progress the total stools of two of the men (R.B., J.M.) were collected each day for 14 days and kept frozen for analysis in England. Table I shows the four men's ages, heights and mean weights, and Fig. 2 shows the changes in bodyweight over 6 months which included the three dietary surveys (two at base, B I and $\mathrm{B}_{2}$, and one while sledging, $\mathrm{S}$ ).

Throughout the 2 years in Greenland, the sledge dogs were weighed regularly and an estimate was made of their dietary intake while working and resting.

Dietary survey at base. The food of each of the men was weighed during two separate periods a month apart. Both surveys on J.M. and R.B. and the first on A.E. and P.W. 
lasted for I week; the second survey on A.E. and P.W. was made for 4 days only. A spring balance with I oz. divisions was used which could be read to $0.5 \mathrm{oz}$. All plates were of standard size and were weighed before the survey. Breakfast, lunch and dinner were supervised by one of the authors (J.M.), who was also a subject. The separate foods served to the men were weighed and recorded and the food left by them was also

Table 1. Description of subjects and their basal metabolic rates

\begin{tabular}{|c|c|c|c|c|c|c|c|}
\hline \multirow[b]{2}{*}{ Subject } & \multirow[b]{2}{*}{$\begin{array}{c}\text { Age } \\
\text { (years) }\end{array}$} & \multirow[b]{2}{*}{$\begin{array}{l}\text { Height } \\
\text { (cm) }\end{array}$} & \multirow[b]{2}{*}{$\begin{array}{c}\text { Mean } \\
\text { weight } \\
(\mathrm{kg})\end{array}$} & \multicolumn{2}{|c|}{ B.M.R. (Cal./sq.m/h) } & \multicolumn{2}{|c|}{ B.M.R. (Cal./min) } \\
\hline & & & & Observed & $\begin{array}{c}\text { Predicted } \\
\text { (Robertson \& } \\
\text { Reid, I952) }\end{array}$ & Observed & $\begin{array}{l}\text { Predicted } \\
\text { (Quenouille } \\
\text { et al. I95I) }\end{array}$ \\
\hline R.B. & 26 & $x 76$ & 77 & $36 \cdot I$ & $37 \cdot 0$ & $I \cdot I 6$ & $x \cdot 19$ \\
\hline J.M. & 25 & I66 & 70 & $38 \cdot 5$ & $37 \cdot 1$ & $1 \cdot 14$ & $1 \cdot 12$ \\
\hline A.E. & 25 & 182 & 83 & $37 \cdot 6$ & $37 \cdot x$ & $1 \cdot 29$ & $I \cdot 26$ \\
\hline P.W. & 23 & 180 & 87 & $37 \cdot 7$ & $37 \cdot 6$ & $1 \cdot 3 I$ & $\mathbf{1} \cdot \mathbf{2 7}$ \\
\hline
\end{tabular}

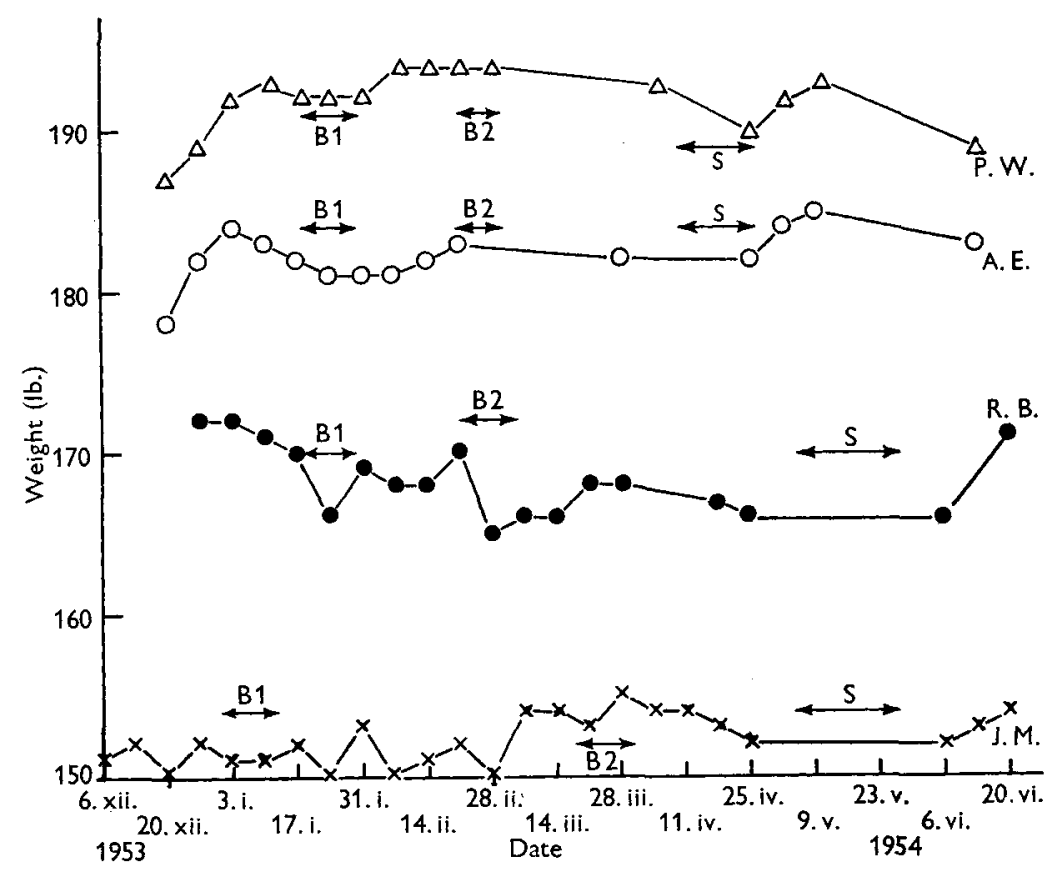

Fig. 2. Body-weights of the four men taking part in the investigation. $B_{1}, B_{2}$ and $S$ indicate the periods over which the three dietary surveys were made (see p. $34^{8}$ ).

weighed, but there was rarely more of it than an ounce or two of vegetable. Second helpings were always available and were frequently taken. The subjects, who were all scientific investigators, weighed their own snacks and 'night-caps' and entered the weights on their log sheets. The amounts of milk and sugar habitually taken by each man in the measured mugful of tea were determined at the beginning of the experiment. Each man was allocated a $\mathrm{r} \mathrm{lb}$. tin of butter which was renewed when it was finished. The exact amount of butter eaten each day was not known, but at the end of the week the total quantity taken was divided proportionately according to the number 
of slices of bread eaten by the man on each particular day: Bread and jam were not weighed each time. The average weight of a slice of bread was determined and the number of slices eaten was recorded. Similarly, the weight of jam required to cover the average slice of bread was measured.

Dietary survey while sledging. The men sledged in pairs. Records of the food intake were made over a I9-day period for J.M. and R.B., and over Io days for A.E. and P.W. Some of the items were already in individual packs of known weight, e.g. biscuits and pemmican. Other foods, such as potato powder, were weighed before the sledging party set off, and the amounts left at the end were also weighed. It was known from experience with the ration that the same quantity of potato powder was always taken with each ration of pemmican. Where excess quantities of foods were taken on certain days they were recorded, as, for example, twice the usual quantity of raisins. Inevitably there were day-to-day inaccuracies, but the total amount of food taken by the two subjects over the whole period was known accurately since the foods that were taken on the trip were weighed initially and the amounts left over on return to base were again measured. There was no plate waste!

Calculation of diets. The composition of the diets was calculated in the main from the tables of McCance \& Widdowson (1946). A few foods, e.g. pemmican, were specially analysed by ourselves for this investigation.

Measurement of energy expenditure. It was not possible to measure the individual energy expenditure of each subject for all activities, but a record was kept of the number of hours a man spent each day on various occupations during the three periods when the dietary surveys were being made. The occupations were divided into five groups: (I) sleeping; (2) sitting (including eating); (3) light work; (4) medium work; (5) heavy work. Whether the work was rated as light, medium or heavy, depended upon subjective impressions. For example, sewing dog harnesses and physiological research were rated as light work, cooking and feeding dogs as medium work, and Scottish dancing, rock scrambling, skiing and humping stores as heavy work. The following figures found in the literature (Edholm, Fletcher, Widdowson \& McCance, I955; Garry, Passmore, Warnock \& Durnin, I955; Passmore \& Durnin, I955) have been taken as the energy cost ( $\mathrm{Cal} . / \mathrm{min})$ of the various activities:

$\begin{array}{lllr}\text { Sitting (including eating) } & 1 \cdot 9 & \text { Medium work } & 5 \cdot 6 \\ \text { Light work } & 3 \cdot 2 & \text { Heavy work } & 12.5\end{array}$

The figures used for the calorie cost of sleeping were the basal metabolic rates of each of the men studied.

Measurement of basal metabolic rates. Measurements were taken from four to seven times on each subject at monthly intervals with a Benedict-Roth spirometer with a Calsoda $\mathrm{CO}_{2}$ absorber. Pure oxygen was used. The subjects had slept $8 \mathrm{~h}$ before the test and they came straight from bed to the laboratory bed where they rested for a further $30 \mathrm{~min}$ before the test began. The oxygen consumption was measured for ro min.

Collection, storage, transport and analysis of faeces. The problem of collecting and preserving stools from two men for 14 days while sledging was simplified by the fact 
that the temperature never exceeded $0^{\circ}$ during the period of the experiment. The stools were passed on to a patch of hard snow and were scooped up without any powdered snow and placed in polythene bags. The faeces froze in a few minutes. Each stool was kept in a separate labelled bag. Back at the base hut the bags were kept in a secure place outside. As the season advanced to summer the temperature began to rise above $0^{\circ}$, but the faeces were kept frozen as long as possible by burying them deeply in the remaining snow drifts. For transport to England they were stored in large Thermos flasks, surrounded by chipped solid carbon dioxide, until placed in a refrigerator in England. When the faeces were finally thawed out they were very soft, almost fluid in consistency. Each man's stool for each day was weighed in the polythene bag and was then tipped out into a beaker and stirred up well. Samples were taken for the determination of water, nitrogen and fat. Water was estimated by drying to constant weight at $100^{\circ}$, nitrogen by the micro-Kjeldahl method after digestion with sulphuric acid and copper selenide, and fat by the method for total fat described by King (1946).

\section{RESULTS}

Comparison of the dietary intakes at the base camp and while sledging. Table 2 shows the mean daily intake of calories and of protein, fat, carbohydrate and alcohol by each of the four men during the two surveys at the base camp and while sledging. For three men the calorie intakes were considerably higher while sledging, but P.W. took more calories during the first survey at base than he did while sledging, and his intake during the second base survey was also high. Both he and A.E. obtained as high a percentage of calories from alcohol during the first base survey as they did from protein, but it was because the Burns Night celebration happened to fall within this particular week. The mean daily fat intakes were considerably higher on the sledging ration $(292 \mathrm{~g})$ than on the diet eaten at the base hut $(\mathrm{I} 63 \mathrm{~g})$. While sledging, all the men obtained $50-60 \%$ of their calories from fat.

Basal metabolic rates. Table I shows the mean basal metabolic rate of the four men. In spite of their 17 months in the Arctic the values for all four were very close to those

Table 2. Comparison of the dietary intakes of four men at the base camp and while sledging

\begin{tabular}{|c|c|c|c|c|c|c|c|c|c|c|c|c|}
\hline \multicolumn{13}{|c|}{ (Mean daily values for each survey) } \\
\hline & \multicolumn{3}{|c|}{ R.B. } & \multicolumn{3}{|c|}{ J.M. } & \multicolumn{3}{|c|}{ A.E. } & \multicolumn{3}{|c|}{ P.W. } \\
\hline Intake & $\begin{array}{c}\text { Base I } \\
(7)\end{array}$ & $\begin{array}{c}\text { Base II } \\
\text { (7) }\end{array}$ & $\begin{array}{l}\text { Sledg- } \\
\text { ing } \\
(\mathrm{rg})\end{array}$ & $\begin{array}{c}\text { Base I } \\
(7)\end{array}$ & $\begin{array}{c}\text { Base II } \\
(7)\end{array}$ & $\begin{array}{l}\text { Sledg- } \\
\text { ing } \\
\text { (19) }\end{array}$ & $\begin{array}{c}\text { Base I } \\
(7)\end{array}$ & $\begin{array}{c}\text { Base II } \\
\text { (4) }\end{array}$ & $\begin{array}{l}\text { Sledg- } \\
\text { ing } \\
\text { (I0) }\end{array}$ & $\begin{array}{c}\text { Base I } \\
(7)\end{array}$ & $\begin{array}{c}\text { Base II } \\
(4)\end{array}$ & $\begin{array}{l}\text { Sledg- } \\
\text { ing } \\
\text { ( } 10)\end{array}$ \\
\hline Calories (Cal.) & 3300 & 3780 & 4850 & 3600 & $357^{\circ}$ & 4520 & 3600 & 3910 & 4870 & $5 \circ 90$ & $444^{\circ}$ & 4840 \\
\hline Protein $(\mathrm{g})$ & 116 & 142 & I 6 & 108 & I 13 & I I O & IOI & 123 & 121 & I 5 I & 153 & I 2 I \\
\hline Fat $(g)$ & 122 & 148 & 285 & 145 & 152 & 273 & I $3 \mathbf{I}$ & 156 & 307 & $24 I$ & 210 & 303 \\
\hline Carbohydrate (g) & 398 & 482 & 458 & 481 & 450 & 406 & 4 II & 470 & 404 & 427 & 454 & 406 \\
\hline Alcohol $(\mathrm{g})$ & 28 & 2 & $\circ$ & $\circ$ & 0 & 0 & 60 & 28 & 0 & 92 & 23 & $\circ$ \\
\hline \multicolumn{13}{|c|}{ Calories (as percentage of total) obtained from: } \\
\hline Protein & $14^{\circ} 4$ & $15 \cdot 4$ & $9 \cdot 8$ & $12 \cdot 3$ & I 3.0 & 10.0 & II.5 & $12 \cdot 9$ & $10 \cdot 2$ & $11 \cdot 9$ & $14 \cdot 1$ & 10.2 \\
\hline Fat & 34.4 & $36 \cdot 4$ & 54.8 & $37 \cdot 5$ & $39 \cdot 6$ & $56 \cdot 2$ & 33.8 & $37 \cdot I$ & $58 \cdot 8$ & $44^{\circ} 0$ & $43 \cdot 8$ & $58 \cdot 2$ \\
\hline Carbohydrate & $45 \cdot 3$ & $47 \cdot 8$ & $35 \cdot 4$ & 50.2 & $47 \cdot 4$ & $33 \cdot \overline{8}$ & $43^{\circ} 0$ & 45.0 & $31 \cdot 0$ & $3 I \cdot 4$ & 38.4 & $3 I \cdot 6$ \\
\hline Alcohol & 5.9 & 0.4 & 0 & $\circ$ & 0 & 0 & $11 \cdot 7$ & 5.0 & o & 12.7 & 3.6 & 0 \\
\hline
\end{tabular}

Figures in parentheses are the number of days of the survey. 
predicted from the tables of Quenouille, Boyne, Fisher \& Leitch (I95I) and of Robertson \& Reid (I952). Thus it is reasonably permissible to use mean values derived from the literature for the energy expended in other occupations, such as sitting and standing and in more strenuous activities.

Time and energy spent at various occupations. Fig. 3 shows how the four men spent their time at the base camp and while sledging. The results for all the days during the two base surveys have been averaged in making the diagram, and the figures for the Io or I9 days' sledging have also been averaged. At the base camp about $8 \mathrm{~h}$ a day were spent in bed, which is very similar to $7.9 \mathrm{~h}$, the figure for the average hours of sleep of all the members of the Expedition over the whole of the 2 years (Lewis 8 Masterton, 1957). Sitting occupied I $\cdot 5 \mathrm{~h}$, of which $4 \mathrm{~h}$ were spent eating meals. An average of $4.5 \mathrm{~h}$ a day was spent on some sort of physical work, but very little of it
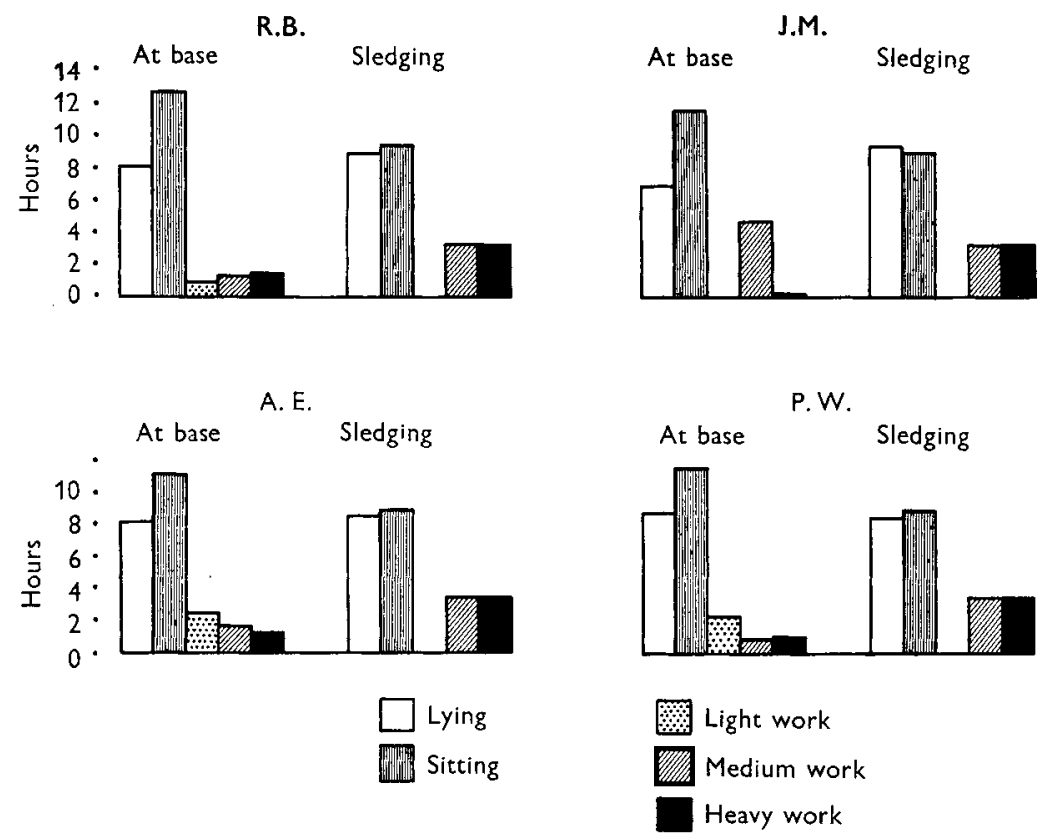

Fig. 3. Mean daily distribution of time spent on different activities by the four men at the base camp and while sledging.

could really be called heavy. While on the sledging trip, the men spent a little longer sleeping ( $8.7 \mathrm{~h}$ a day), and less time sitting ( $8.9 \mathrm{~h}$ a day) than they did at the base camp. It may seem surprising that on a sledging expedition in the Arctic, with temperatures always below freezing and often below $-18^{\circ}$, the men should spend 17.5 h out of every 24 lying or sitting inside their tent. However, $6.5 \mathrm{~h}$ a day were spent on heavy work, which accounted for $69 \%$ of the total energy expenditure. This value was very constant from one man to the other because the patterns of the men's days were very similar. At base, medium and heavy work accounted for much less of each man's energy expenditure. It varied from $26 \%$ for P.W. during the first base survey to $52 \%$ for J.M. during the second. Two men (R.B. and A.E.) were more energetic during the first base survey, and the other two during the second. 
Total energy expenditure. Table 3 shows the mean daily energy expenditure of each of the four men during the three surveys, and the daily energy balance, which is the difference between the figure for energy expenditure and that given in Table 2 for the mean daily calorie intake. If the estimates of the energy expended while sledging are nearly correct, all the men expended more calories than they took in while sledging. At base R.B., J.M. and A.E. were in positive energy balance during one survey and in negative during the other, and their overall intakes just about matched their expenditures. P.W., however, who ate much more food than the others during both base surveys, expended no more energy. He had been gaining a little weight at the beginning of the investigation (Fig. 2), but not later. If the figures for his expenditures are not far wrong one must conclude that he ate less at other times.

Table 3. Mean daily values for energy expenditure and balance (Cal.) of four men at the base camp and while sledging

\begin{tabular}{lcccc} 
Survey & R.B. & J.M. & A.E. & P.W. \\
Base I & 3706 & 3442 & 3778 & 3618 \\
& $(-406)$ & $(+\mathrm{I} 5)$ & $(-\mathrm{I} 78)$ & $(+\mathrm{I} 472)$ \\
Base II & 33 I0 & 3666 & 3563 & 3566 \\
\multirow{3}{*}{ Sledging } & $(+470)$ & $(-96)$ & $(+347)$ & $(+874)$ \\
& 5 II & 5013 & 53 II & 5349 \\
& $(-269)$ & $(-493)$ & $(-44 \mathrm{I})$ & $(-509)$
\end{tabular}

Figures in parentheses denote energy balances.

Variation in calorie intake and expenditure from day to day. Fig. 4 shows the calorie intake and expenditure of the four men on each of the days of the three surveys.

In the first base survey, the daily calorie intake of each man varied greatly. This survey was made in January; there was no daylight; little work could be done, and the men were bored by the long winter's inactivity. They had plenty of time to think about food, and to eat to excess if they wished, only to eat smaller meals on the following day.

By the time the second survey was carried out the men were busy preparing for the spring work and were less preoccupied with food. The sun had returned, and enthusiasm for the ensuing season followed immediately.

On the sledging journeys, the calorie intakes were fairly constant from day to day. The expenditures varied much more. Thus, on 2 days of R.B.'s and J.M.'s trip, they did no sledging at all and lay up in the tent because of bad weather, and A.E. and P.W. only did $\mathrm{I} \cdot 5 \mathrm{~h}$ sledging on one of their days. After days of enforced inactivity, the men had particularly strenuous days.

Faecal excretions. Table 4 shows the weight and composition of the faeces passed by two of the men sledging, and Table 5 the intakes, excretions and absorptions of nitrogen and fat. The weight of the dry faeces was perhaps higher than might have been expected on a diet which contained so little 'roughage' but, although the fat intakes were about $280 \mathrm{~g}$ a day, the percentage of fat in the dry faeces was well within normal limits. The proportion of nitrogen in the dry faeces was also normal.

Body-weights and calorie intakes of the husky dogs. By the time the survey was made the Expedition dogs were all fit and able to cope with the work required of them. Many 

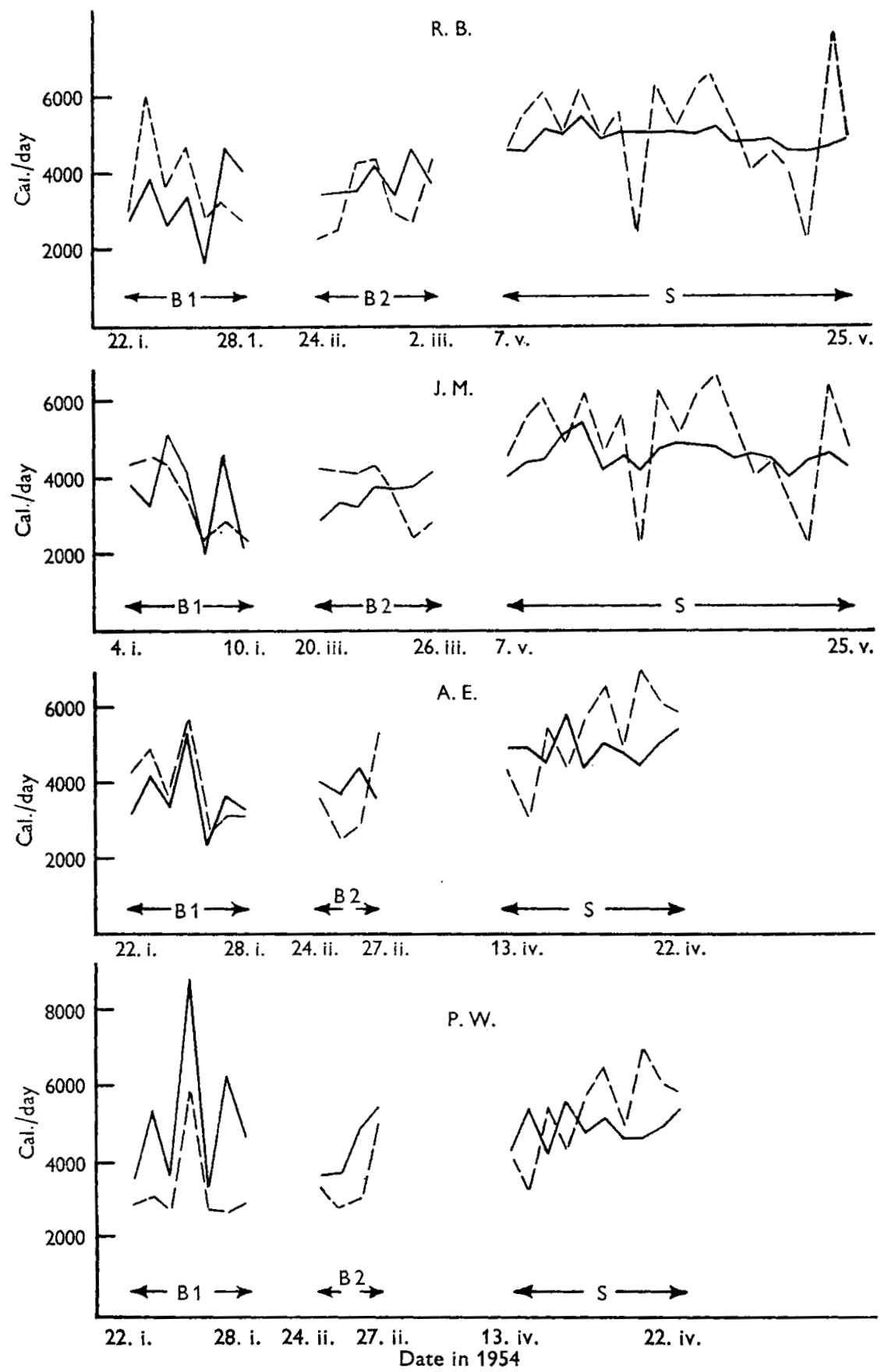

Fig. 4. Daily energy intakes and expenditures of the four men. ___, intake; - - - , expenditure; $\mathrm{B}_{1}$, first base survey; $\mathrm{B}_{2}$, second base survey; $\mathrm{S}$, sledging survey. 
had been in bad condition the previous year; they had been extremely seasick on the voyage from west Greenland, and soon after were taken on a long, hard, sledge journey, on which some died. The mean weight of the forty adult dogs at their prime was $32 \mathrm{~kg}$ (range $24-50 \mathrm{~kg}$ ). While sledging, the dogs ate $\mathrm{I}-\mathrm{I} \frac{1}{2} \mathrm{lb}$. dog pemmican each day, together with odd pieces of blubber or other fat. Dog pemmican is made from powdered meat, fat, bone meal and vitamin supplements; I lb. yields about $2300 \mathrm{Cal}$., so that the sledging ration provided the dogs with 2500-3500 Cal./day. The daily ration at base was $1 \frac{1}{2}-2 \mathrm{lb}$. dried halibut, together with scraps from the mess. The halibut probably provided about I600 Cal./day. In the U.S. Yearbook of Agriculture (U.S. Department of Agriculture, I939) it is suggested that dogs weighing $35 \mathrm{~kg}$ require $3^{1} 100 \mathrm{Cal}$./day for hard work, and $\mathrm{r} 800 \mathrm{Cal}$./day for maintenance, so the actual rations provided could not be considered inadequate, a view confirmed by the fact that the dogs were in good health during the tests and were not losing weight.

Table 4. Mean values for the weight and composition of faeces of two men on the sledging diet for 14 days

\begin{tabular}{|c|c|c|c|c|}
\hline \multirow[b]{2}{*}{ Subject } & \multicolumn{2}{|c|}{$\begin{array}{l}\text { Weight } \\
\text { (g/day) }\end{array}$} & \multirow{2}{*}{$\begin{array}{l}\text { Nitrogen con- } \\
\text { tent }(\mathrm{g} / \mathrm{roo} \mathrm{g} \\
\text { dry weight) }\end{array}$} & \multirow{2}{*}{$\begin{array}{l}\text { Fat content } \\
\text { (g/roog } \\
\text { dry weight) }\end{array}$} \\
\hline & Fresh & Dry & & \\
\hline $\begin{array}{l}\text { R.B. } \\
\text { J.M. }\end{array}$ & $\begin{array}{l}164 \\
162\end{array}$ & $\begin{array}{l}39 \cdot 3 \\
40.5\end{array}$ & $\begin{array}{l}6 \cdot 9 \\
6 \cdot 7\end{array}$ & $\begin{array}{l}22 \cdot 3 \\
23 \cdot 7\end{array}$ \\
\hline
\end{tabular}

Table 5. Mean values for intake and absorption of nitrogen and fat by two men on the sledging diet for $\mathrm{I}_{4}$ days

\begin{tabular}{|c|c|c|c|c|}
\hline \multirow[b]{2}{*}{ Subject } & \multirow[b]{2}{*}{$\begin{array}{l}\text { Intake } \\
\text { (g/day) }\end{array}$} & \multirow{2}{*}{$\begin{array}{c}\text { Excretion } \\
\text { in faeces } \\
\text { ( } \mathrm{g} / \text { day) }\end{array}$} & \multicolumn{2}{|c|}{ Absorption } \\
\hline & & & g/day & $\begin{array}{l}\text { As percentage } \\
\text { of intake }\end{array}$ \\
\hline $\begin{array}{l}\text { R.B. } \\
\text { J.M. }\end{array}$ & $\begin{array}{l}18 \cdot 5 \\
17.6\end{array}$ & $\begin{array}{c}\text { Nitrogen } \\
2 \cdot 7 \\
2 \cdot 7\end{array}$ & $\begin{array}{l}15.8 \\
14.9\end{array}$ & $\begin{array}{l}85.4 \\
84 \cdot 6\end{array}$ \\
\hline $\begin{array}{l}\text { R.B. } \\
\text { J.M. }\end{array}$ & $\begin{array}{l}285 \\
273\end{array}$ & $\begin{array}{l}\text { Fat } \\
9 \cdot 0 \\
10 \cdot 0\end{array}$ & $\begin{array}{l}276 \\
263\end{array}$ & $\begin{array}{l}96 \cdot 8 \\
96 \cdot 3\end{array}$ \\
\hline
\end{tabular}

\section{DISCUSSION}

The energy expenditure of the four men while on their sledging trip must be rated as very high, similar indeed to that of lumbermen who are the classical examples of very heavy workers. Karvonen \& Turpeinen (1954), for example, found that during a 4 -day competition, with an average $5 \mathrm{~h}$ work daily, lumbermen ate food providing $5460 \mathrm{Cal}$./ day and on this intake lost a little weight. Durnin (1955) has pointed out that climbing with a load, although it may not require more calories per hour, is usually continued for more hours a day than lumbering, which is often limited by daylight. He calculates that the total energy expenditure on a climbing expedition is likely to be about $5900-7300 \mathrm{Cal}$./day on the assumption that $7 \mathrm{~h}$ a day are spent climbing, and $3 \mathrm{~h}$ going 
downhill. Our subjects spent about $6.5 \mathrm{~h}$ a day out of doors with their sledges, and were doing very hard work for at least half of this time.

While the men were living at the base camp most of their time was spent in a warm environment, and their total calorie intakes and expenditures were very similar to those of cadets at a military establishment in England (Widdowson, Edholm \& McCance, I954; Edholm et al. 1955), and they were also of the same order as those of miners in Scotland (Garry et al. I955). Swain, Toth, Consolazio, Fitzpatrick, Allen \& Koehn (1949) made a survey of the amount of food eaten by soldiers stationed at Fort Churchill in Manitoba during the winter months and found that the diets provided more than $5500 \mathrm{Cal}$./day. Fort Churchill is a very cold, windy place, and this fact is emphasized throughout the paper, but the men were living in a camp, which was presumably heated, and they only spent $3 \mathrm{~h}$ a day out of doors. Nothing is said about the indoor temperature, but it is likely to have been quite warm. This is a point which must always be borne in mind in any discussion of life in Arctic and Antarctic regions.

Sledging diets in polar regions contain a high proportion of fat in order to reduce the weight which must be carried to provide a given amount of energy. The weight of rations is of vital importance, since all the food for two men and a team of nine dogs has to be carried on the sledge. In addition to food, there is gear and scientific equipment totalling as much as $600-800 \mathrm{lb}$. In spite of high fat intakes subjects R.B. and J.M. absorbed more than $96 \%$ of the fat in their food, which is within what is generally considered to be the normal range of $95-98 \%$ (Wollaeger, Comfort, Weir \& Osterberg, 1946). Butson (1950) made a similar investigation on members of the Falkland Islands Dependencies Survey team and found that four men eating a sledging ration almost identical with the present one produced about $30 \mathrm{~g}$ faeces (dry weight) daily. This finding is similar to ours, but the faeces of three of the men described by Butson contained an average of $82 \%$ of fat on a dry-weight basis. The fourth man, who was considered to have had a particularly high fat tolerance, gave results similar to those found in the present investigation, his faeces containing $20 \%$ fat on a dry-weight basis. Why the results for the first three men should have been so different from those for the fourth and from those found by us it is impossible to say.

The present results do not explain why husky dogs like to eat human faeces in preference to other foods. This coprophagic habit has been observed both among the dogs belonging to Eskimo or polar-Indian settlements and among dogs used by explorers. In permanent Eskimo or Greenlander settlements the husky dog is essentially a worker during the 9 months or so of freezing temperatures. The dogs are fed on dried fish and the flesh of seal, walrus or other game, and they work hard by transporting men and goods over the sea-ice and snow fields. In summer they do no work, and in the rigid economy of the polar regions they are not fed regularly, but have to find much of their food by scavenging. Ample offal from summer fishing is, however, generally available. In both summer and winter the dogs eat human faeces and so keep the settlement free of this 'nuisance'; they eat faeces in preference to dried fish offered to them. Our findings only serve to show that it is not because the faeces contain a particularly high proportion of fat, and it does not seem as though their energy value can be very important. R.B.'s and J.M.'s stools would each have provided $\mathrm{r} 9 \circ \mathrm{Cal}$./day. 
There were more than twice as many dogs as men at the base camp, and more than four times as many on a sledging expedition, so if all the faeces were fairly divided among all the dogs, each would have been able to obtain only about 50-100 Cal./day extra. Husky dogs are not the only animals that eat human faeces. In villages in India 'pi-dogs' and pigs follow the people out in the morning, and there is a competition between them for the human excreta. In some parts of Africa cattle do the same thing. Sparrows and other small birds peck out the grain from horse droppings, and snipe dig through cow droppings for grubs. Cats always eat the faeces of their kittens for the first 4 weeks or so after birth. It must be concluded that the eating of faeces is for some animals a natural rather than an unnatural thing to do.

\section{SUMMARY}

I. Dietary surveys and measurements of the time spent at different activities were made on four men, members of the British North Greenland Expedition. Two of these surveys were made at the base camp and one during a sledging expedition. The faeces of two of the men were collected on the sledging expedition and brought to England for analysis.

2. At the base camp the men's food provided 3000-4000 Cal./day (except for one man who took 4000-5000 Cal.). While sledging the men took about $4800 \mathrm{Cal}$./day.

3. The estimated daily energy expenditures generally corresponded to the calorie intakes at the base camp, but were greater than the intakes when the subjects were sledging.

4. Although the men ate $270 \mathrm{~g}$ fat a day while sledging they absorbed $96 \%$ of it and their faeces contained only $23 \%$ fat on a dry-weight basis, a figure within normal limits. The percentage of nitrogen in the faeces was also quite normal.

5. The present results offer no physiological reason why husky dogs eat human faeces in preference to other food, but other animals and birds commonly eat the faeces of other species and this practice is more likely to be natural than unnatural.

The authors are very grateful to the three subjects, R.B., A.E. and P.W., for their co-operation, and especially to Lieut. A. B. Erskine, R.N., for further assistance with the compilation of the data. They also thank Mr J. W. T. Dickerson and Mr W. Skipsey for help over the chemical analyses, and Petty Officer D. E. Lee for his share in the calculation of the results. Professor R. A. McCance and Dr O. G. Edholm have taken a continued interest in this investigation and have made many valuable suggestions.

\section{REFERENCES}

Bertelsen, A. (1929). In Greenland, 3, 363. [M. Vahl, G. C. Amdrup, L. Bobé and A. S. Jensen, editors.] Copenhagen: Reitzel.

Butson, A. R. C. (1950). Lancet, 258, 993.

Durnin, J. V. G. A. (1955). F. Physiol. 128, 294.

Edholm, O. G., Fletcher, J. G., Widdowson, E. M. \& McCance, R. A. (1955). Brit. F. Nutr. 9, 286.

Garry, R. C., Passmore, R., Warnock, G. M. \& Durnin, J. V. G. A. (1955). Spec. Rep. Ser. med. Res. Coun., Lond., no. 289 .

Karvonen, M. J. \& Turpeinen, O. (1954). F. appl. Physiol. 6, 603. 
King, E. J. (1946). Micro-Analysis in Medical Biochemistry. London: J. \& A. Churchill.

Lewis, H. E. \& Masterton, J. P. (1955a). Lancet, 269, 494.

Lewis, H. E. \& Masterton, J. P. (1955 b), Lancet, 269, 549.

Lewis, H. E. \& Masterton, J. P. (1957). Lancet, 272, I 262.

McCance, R. A. \& Widdowson, E. M. (1946). Spec. Rep. Ser. med. Res. Coun., Lond., no. 235, and ed.

Passmore, R. \& Durnin, J. V. G. A. (1955). Physiol. Rev. 35, 801.

Quenouille, M. H., Boyne, A. W., Fisher, W. B. \& Leitch, I. (195I). Tech. Commun. Bur. Anim. Nutr., Aberd., no. 17.

Robertson, J. D. \& Reid, D. D. (1952). Lancet, 262, 940.

Rosendahl, P. (1954). The Dog's Bulletin, October, p. 3. (London: National Canine Defence League.)

Swain, H. L., Toth, F. M., Consolazio, F. C., Fitzpatrick, W. H. Allen, D. I. \& Koehn, C. J. (1949). F. Nutr. $\mathbf{3}^{8}, 63$.

U.S. Department of Agriculture (1939). Yearb. Agric. U.S. Dep. Agric., p. 852.

Widdowson, E. M., Edholm, O. G. \& McCance, R. A. (1954). Brit. F. Nutr. 8, 147.

Wollaeger, E. E., Comfort, M. W., Weir, J. F. \& Osterberg, A. E. (I946). Gastroenterology, 6, 83.

\title{
The relative value of three cereals as protein sources for growing chicken
}

\author{
By K. J. CARPENTER* AND K. MARY CLEGG $\dagger$ \\ Rowett Research Institute, Bucksburn, Aberdeenshire
}

(Received 22 March 1957)

The prime consideration for the relative replacement values of the common cereals in poultry nutrition is their contribution of energy (either 'metabolizable' or 'productive'). However, they also contribute from one-third to two-thirds of the total protein in the diet. There have been suggestions that the usefulness of this nitrogen fraction differs significantly from one cereal to another and that there may be mutual supplementation within a mixture of several cereals. The published biological values of maize as a protein source for rats are lower than those for barley, oats and wheat (see review by Block \& Mitchell, r946-7).

Investigation of the protein value of cereals requires rigorous control if misleading results due to differences in the palatability and the energy content of the experimental rations are to be avoided. Also, in practice the cereal proteins are fed together with protein from one or more concentrates. Not every combination can be investigatedin the present work we have used two contrasting concentrates, one of high quality (white-fish meal) and one of low (groundnut meal). Nor was it possible to use more than a single sample each of barley, maize and oats.

We used individually caged growing chickens and measured their nitrogen retention on different rations in the same general way as described by Wilgus, Norris \& Heuser (1935). Each bird was fed according to a scale based on live weight so as to provide the same constant daily intake of metabolizable energy, crude fibre and crude protein

* Present address: School of Agriculture, Cambridge.

$\dagger$ Present address: Cereals Research Station, St Albans, Hertfordshire. 